\title{
In vitro and In vivo Antioxidant Property of Novel 2-phenyl Quinazoline 4-(3H)-one Derivatives
}

\author{
Praveen Kumar Kusuma ${ }^{1}$ and Girijasastry Vedula ${ }^{2 *}$ \\ ${ }^{1}$ Medicinal Chemistry Research Lab, Vaagdevi College of Pharmacy, \\ Kishanpura, Hanamkonda, Warangal-506001, India. \\ ${ }^{2}$ Department of Pharmaceutical Sciences, College of Pharmacy, Andhra University, \\ Visakhapatnam - 530003, India. \\ http://dx.doi.org/10.13005/bbra/2141
}

(Received: 01 April 2016; accepted: 20 May 2016)

\begin{abstract}
Heterocyclic chemistry comprise as a minimum half of all organic chemistry research worldwide. In particular, heterocyclic structures form the basis of a lot of pharmaceutical, agrochemical and veterinary products. Quinazoline nucleus is a very attractive and useful scaffold in medicinal chemistry. The synthesized compounds were screened for in vitro and in-vivo antioxidant activity. The presence of antioxidants has been reported to protect lipids, blood and body fluids against the attack of reactive oxygen species like peroxide, superoxide and hydroxyl radicals. The presence of antioxidants in Test compounds (7a1, 7a2, 7a3, 7a4, 7a5, 7a6, 7a7, 7a8, 7b1, 7b2, 7b3, 7b4, 7b5, 7b6, 7b7 \& 7b8) might be responsible for their observed antioxidant activity.
\end{abstract}

Key words: Quinazoline, Peroxide, Superoxide, Antioxidant activity.

Quinazolines are classes of fused heterocycles compound made up of two fused sixmembered simple aromatic rings, a benzene ring and a pyrimidine ring ${ }^{1,2}$. Quinazolines and their derivatives are building block for approximately 150 naturally occurring alkaloid isolated from a number of families of the plant kingdom, from microorganisms and animals and are now known for a broad range of biological properties including anti inflammatory, anti-tumoral, antibacterial, antidiabetic, anticonvulsant hypnotic, sedative and several other useful and interesting properties $^{3}$.

Oxidative stress is defined as a condition in which the level of toxic reactive oxygen intermediates (ROI) overcomes the endogenous antioxidant defenses of the host. Toxic reactive oxygen intermediates (ROI) are produced by phagocytic cells following injury and inflammation

\footnotetext{
* To whom all correspondence should be addressed.

E-mail: vgirijasastry@yahoo.co.in
}

of tissues as a mechanism to kill invading microorganism ${ }^{4,5}$. When inflammation becomes systemic as in inflammatory response syndrome there is loss of control of ROI production leading to non-discriminant injury of tissues and organs in the host. Oxidative stress has been shown to cause secondary damage through delayed cellular death and inflammation. Therefore, minimizing oxidative stress may prevent cellular death, decrease inflammation, and prevent some morbidity and mortality ${ }^{6}$.

Antioxidants are believed to play a very chief key role in the body defense system against reactive oxygen species, which are the dangerous by products, generate during normal cell aerobic respiration ${ }^{7}$. Many of the recent research have acknowledged that antioxidants are radical scavengers, which protect the human body against free radicals that may cause pathological circumstances such as anaemia, asthma, ischemia, arthritis, inflammation, neuro-degenertion, and ageing process ${ }^{8}$.

Lipid peroxidation is also powerfully 
associated with aging and carcinogenesis ${ }^{9}$. However, living systems are protected from active oxygen species by enzymes such as glutathione peroxidase, glutathione reductase, superoxide dismutase, and catalase ${ }^{10}$. Generally, food antioxidants act as anti-oxidant agents, reversing oxidation by donating electrons and hydrogen ions. There is a universal trend toward the use of natural antioxidants.

Therefore, the present study we have screened the antioxidant activity of Test compounds (7a1, 7a2, 7a3, 7a4, 7a5, 7a6, 7a7, 7a8, $7 \mathrm{~b} 1,7 \mathrm{~b} 2,7 \mathrm{~b} 3,7 \mathrm{~b} 4,7 \mathrm{~b} 5,7 \mathrm{~b} 6,7 \mathrm{~b} 7$ \& 7b8) demonstrates against $\mathrm{CCl}_{4}$ induced rats models of erythrocyte damage by assessment of anti-oxidant enzymes such as and the catalase, superoxide dismutase (SOD), glutathione peroxidase, lipid peroxidation and glutathione reductase as biomarkers.

\section{MATERIALSAND METHODS}

The reagents/ chemical/solvents used for these studies were obtained from SD fine, Merck (India) and Sigma Aldrich. The solvents are purified by distillation before their use.

Synthesis

\section{Synthesis of (1) from Anthranilic acid}

To a cold solution of anthranilic acid $(0.05$ $\mathrm{mol})$ in dry pyridine $(25 \mathrm{ml})$ and benzoyl chloride $(0.1 \mathrm{~mol})$ was added drop wise and stirred for $4 \mathrm{hrs}$ at $0-5^{\circ} \mathrm{C}$. The reaction was monitored by TLC and then poured into $100 \mathrm{ml}$ ice cold water and precipitate formed was collected by filtration. If precipitate is not found, neutralized the solution with dil.HCI. Recrystalized from ethanol.

\section{Synthesis of (2) from (1)}

An equimolar mixture $(0.01 \mathrm{~mol})$ of $(1)$ and Para amino benzoic acid (PABA) was taken mixed and mixture was refluxed for $6 \mathrm{hrs}$ in $10 \mathrm{ml}$ of dry pyridine. Up on cooling the mixture was poured in crushed ice. Then precipitated solid was collected and recrystalised from ethanol to give the desired title compounds (2).

\section{Synthesis of (3) from (2)}

$3 \mathrm{ml}$ of Thionyl chloride and compound (2) (0.02moles) in $25 \mathrm{ml}$ of 1,4 dioxane in a Round Bottomed Flask and refluxed for $6 \mathrm{hrs}$. After end of reaction; the excess of thionyl chloride was evaporated. The crude product was precipitated and poured into $100 \mathrm{ml}$ of ice cold water. The product was recrystalised from 1, 4 dioxane as brownish white crystal solid (3) (yield 5gr; 85\%, Melting point $92^{\circ} \mathrm{C}$ ). The product was column chromatographed on silica gel eluting with ethyl acetate: methanol $(1: 1)$.

\section{Synthesis of (4) from (3)}

L-glutamic acid (0.013 moles) was dissolved in $10 \mathrm{ml}$ of $0.1 \mathrm{~N} \mathrm{NaOH}$ solution and to this a solution of compound ( 3 ) ( 0.013 moles) in 10 $\mathrm{ml}$ of 1,4 dioxane was added and the mixture was refluxed for 8 hours. The crude product was precipitated by poured in to $50 \mathrm{ml}$ of $1 \mathrm{~N} \mathrm{HCl}$. The crude product was recrystalised from aqueous ethanol. The product was column chromatographed on silica gel eluting with ethyl acetate: methanol $(1: 1)$.

Synthesis of (5) from (4)

Take clean dry $\mathrm{RBF}$ fitted with $\mathrm{CaCl}_{2}$ guard tube, $0.066 \mathrm{moles}$ of (4) was taken and $25 \mathrm{ml}(0,264$ moles) of freshly distilled $\mathrm{POCl}_{3}$ was added to it gradually with cooling of the flask in ice bath. Then 2-3 drops of DMF (Di Methyl Formamide) was added and the reaction mixture stirred for 3-4 $\mathrm{h}$ at room temperature. The reaction mixture was poured with stirring in to crush ice and he precipitate formed was extracted in chloroform. Chloroform extract dried over anhydrous $\mathrm{MgSO}_{4}$. Removal of solvent gave compound (5) in pure form.

\section{Synthesis of (6) from (5)}

Compound (5) was converted to (6) by heating at $70^{\circ}$ for an hour with $15 \mathrm{ml}$ of $\mathrm{SOCl}_{2}$ (Thionyl chloride) and with addition of 2 drops of DMF (Dimethylformamide) and removing the excess of $\mathrm{SOCI}_{2}$ by vacuum distillation.

\section{Synthesis of (7) from (6)}

Synthesis of compound (7) was achieved by adding gradually to a solution of $0.012 \mathrm{~mol}$ of compound (6) in $5 \mathrm{ml}$ of chloroform $0.020 \mathrm{~mol}$ Different amine dissolved in $5 \mathrm{ml}$ of chloroform with temperature maintained at $0^{\circ} \mathrm{C}$. The temperature was then raised to $50{ }^{\circ} \mathrm{C}$ and the mixture heated for 5-6hrs. The chloroform solution was washed several times with water to remove unreacted amine, dried and then concentrated in vacuum. The amide obtained was purified by recrystallization with aqueous methanol or with ethyl acetate-hexane mixture (4:1).

In-vitro Models for the Evaluation of Antioxidant Activity 


\section{DPPHMethod}

The free radical scavenging activity by different Test compounds (7a1, 7a2, 7a3, 7a4, 7a5, 7a6, 7a7, 7a8, 7b1, 7b2, 7b3, 7b4, 7b5, 7b6, 7b7 \& $7 b 8$ ) was done according to the method reported ${ }^{11}$. Fifty micro liters of the each test compounds in methanol, yielding $100 \mathrm{ig} / \mathrm{ml}$ respectively in each reaction was mixed with $1 \mathrm{ml}$ of $0.1 \mathrm{mM} \mathrm{DPPH}$ in methanol solution and $450 \mathrm{il}$ of $50 \mathrm{mM}$ Tris-HCl buffer (pH 7.4). Methanol (50il) only was used as control of experiment. After 30 min of incubation at room temperature the reduction of the DPPH free radical was measured reading the absorbance at $517 \mathrm{~nm}$. Ascorbic acid used as standard. The percent inhibition was calculated from the following equation:

$\% \quad \mathrm{DPPH} \quad$ radical-scavenging = $\frac{(\text { Absorbance of control }- \text { Absorbance of test sample })}{(\text { Absorbance of control })} \times 100$

\section{Reducing Power Method}

The assay of reducing power method ${ }^{11}$ is one to determine the antioxidant activity. In this 1 $\mathrm{ml}$ of test compounds (7a1, 7a2, 7a3, 7a4, 7a5, 7a6, 7a7, 7a8, 7b1, 7b2, 7b3, 7b4, 7b5, 7b6, 7b7 \& 7b8) mixed with $2.5 \mathrm{ml}$ phosphate buffer $(0.2 \mathrm{M}, \mathrm{pH} 6.6)$ and $2.5 \mathrm{ml}$ Potassium Ferricyanide $\left[\mathrm{K}_{3} \mathrm{Fe}(\mathrm{CN} 6)\right]$ $(10 \mathrm{~g} / \mathrm{l})$ and the mixture was incubated at $50^{\circ} \mathrm{C}$ for 20 minutes and add $2.5 \mathrm{ml}$ of Tri chloroacetic acid $(100 \mathrm{~g} / \mathrm{l}$. This was centrifuged at $3000 \mathrm{rpm}$ for 10 min. Finally $2.5 \mathrm{ml}$ of the supernantant solution was mixed with $2.5 \mathrm{ml}$ of distilled water and $0.5 \mathrm{ml}$ $\mathrm{FeCl}_{3}(\mathrm{lg} / \mathrm{L})$ and absorbance was measured at $700 \mathrm{~nm}$ in UV- visible spectrophotometer (SHIMADZU UV1700, UV-visible spectrophotometer). Ascorbic acid was used as standard and phosphate buffer used as blank.

\section{In vivo antioxidant studies Experimental Animals}

Wister albino rats weighing between 150 $220 \mathrm{gm}$ each were used for this experiment. They were procured from Vaagdevi College of Pharmacy, Warangal, Telangana, India. The animals were keeped in a well-ventilated room with at 12:12 hr light, dark cycle in polypropylene cages and maintained at $22 \pm 1$ ÚC with humidity at $55 \pm 5 \%$. They were fed balanced rodent pellet diet and tap water ad libitum throughout the experimental period. Ethical committee clearance was obtained from IAEC (Institutional Animal Ethics Committee) of IAEC NO: 1047/ac/a/CPCSEA.

\section{Acute Toxicity Study}

The acute toxicity of Test compounds (7a1, 7a2, 7a3, 7a4, 7a5, 7a6, 7a7, 7a8, 7b1, 7b2, 7b3, $7 \mathrm{~b} 4,7 \mathrm{~b} 5,7 \mathrm{~b} 6,7 \mathrm{~b} 7 \& 7 \mathrm{~b} 8$ ) were determined as per the OECD guideline no. 423 (Acute Toxic Class Method). It was observed that the Test compounds (7a1, 7a2, 7a3, 7a4, 7a5, 7a6, 7a7, 7a8, 7b1, 7b2, 7b3, $7 \mathrm{~b} 4,7 \mathrm{~b} 5,7 \mathrm{~b} 6,7 \mathrm{~b} 7$ \& $7 \mathrm{~b} 8$ ) were not mortal even at $50 \mathrm{mg} / \mathrm{kg}$ dose. Hence, $1 / 5^{\text {th }}(10 \mathrm{mg} / \mathrm{kg})$ of this dose were selected for further study ${ }^{12}$.

\section{Experimental design}

Body weight of animals was recorded and then they were divided into 6 groups of 6 rats each. $1 \%$ Tween 80 was used as a vehicle of extracts as well as for carbon tetrachloride $(1 \mathrm{ml} / \mathrm{kg}$ body weight), administered intraperitoneally alternate days for 14 days. On the $8^{\text {th }}$ day all group of animals were kept fasting for 12 hours and sacrificed by cervical dislocation. Blood was collected from the jugular vein into tubes containing heparin (anticoagulant), centrifuged at $3000 \mathrm{rpm}$ for $15 \mathrm{~min}$ and the resulting buffy coat removed. The packed cells were washed three times with physiological saline $(0.9 \% \mathrm{NaCl})$, lysed by suspending them in cold distilled water, and then centrifuged at 7000rpm for $30 \mathrm{~min}$. The resulting pellet contained the erythrocyte membrane and the supernatant represent the haemolysate.

\section{Biochemical estimation}

Plasma ensuing from the initial centrifugation was used for measuring lipid peroxidation following the method of Gutteridge and Wilkins ${ }^{13}$ while the haemolysate was used for the estimation of superoxide, catalase, Glutathione reductase and glutathione peroxidase activities ${ }^{14-}$ 17.

\section{Estimation of Lipid Peroxidation}

Lipid peroxidation in the plasma sample was determined by measuring the amounts of malondialdehyde ${ }^{13} .0 .2 \mathrm{ml}$ of plasma sample, $0.2 \mathrm{ml}$ of sodium dodecyl sulphate, $1.5 \mathrm{ml}$ of $20 \%$ acetic acid and $1.5 \mathrm{ml}$ of thiobarbituric acid were added. The volume of the mixture was made up to $4.0 \mathrm{ml}$ with distilled water and then heated at $95^{\circ} \mathrm{C}$ for 60 min. After incubation the tubes be cooled to room temperature and final volume was made to $5.0 \mathrm{ml}$ in each tube. $5.0 \mathrm{ml} \mathrm{n}$-butanol pyridine (15: 1) mixture was added and the contents were vortexed thoroughly for 2 minutes. After centrifugation at $3000 \mathrm{rpm}$ for $10 \mathrm{~min}$, the organic upper layer was 
taken and its optical density read at $532 \mathrm{~nm}$ against an appropriate blank.

The levels of lipid peroxides were expressed as $n$ moles of malondialdehyde (MDA)/ $\mathrm{min} / \mathrm{mg}$ protein in plasma sample.

\section{Estimation of Superoxide Dismutase}

Superoxide dismutase was assayed by Marklund and Marklund, 1974. Method ${ }^{14}$. To $1 \mathrm{ml}$ of the sample, $0.25 \mathrm{ml}$ of absolute ethanol and 0.15 $\mathrm{ml}$ of chloroform were added. After $15 \mathrm{~min}$ of shaking in a mechanical shaker, the suspension was centrifuged and the supernatant obtained constituted the enzyme extract. The reaction mixture for auto-oxidation consisted of $2 \mathrm{ml}$ of buffer, 0.5 $\mathrm{ml}$ of $2 \mathrm{mM}$ pyrogallol and $1.5 \mathrm{ml}$ of water. Initially the rate of auto-oxidation of pyrogallol was noted at an interval of $1 \mathrm{~min}$ for $3 \mathrm{~min}$. the assay mixture for the enzyme contained $2 \mathrm{ml}$ of $0.1 \mathrm{M}$ Tris $-\mathrm{HCl}$ buffer, $0.5 \mathrm{ml}$ of pyrogallol, aliquots of the enzyme preparation and water made up to $4 \mathrm{ml}$. The rate of inhibition of pyrogallol auto-oxidation after the addition of the enzyme was noted. The superoxide dismutase activity was measured by the inhibition of pyrogallol auto-oxidation at $420 \mathrm{~nm}$ for $10 \mathrm{~min}$. One unit of superoxide dismutase is the amount of enzyme required to bring about $50 \%$ inhibition of auto-oxidation by pyrogallol. The enzyme activity was expressed in terms of units $/ \mathrm{min} / \mathrm{mg}$ protein.

\section{Estimation of Catalase}

Catalase of tissue homogenate was estimated according to the method of Beers RF and Sizer IW (1952) ${ }^{15}$. Plasma sample (haemolysate) with $\mathrm{M} / 15$ phosphate buffer at 1 to $4{ }^{\circ} \mathrm{C}$ and centrifuged. Stirred the sediment with cold phosphate buffer and allowed to stand in the cold condition with occasional shaking. Repeat the extraction once or twice, supernatants are combined and used for assay. $3 \mathrm{ml}$ of $\mathrm{H}_{2} \mathrm{O}_{2}$ phosphate buffer was taken in one cuvette added $0.01-0.04 \mathrm{ml}$ sample and read against a control cuvette containing enzyme solution without $\mathrm{H}_{2} \mathrm{O}_{2}$ phosphate buffer at $240 \mathrm{~nm}$. "t was noted for a decrease in the optical density from 0.450 to 0.400 . This value was used for the calculations.

\section{Estimation of Glutathione Reductase}

Glutathione reductase activity of sample was measured by the method of Dobler and Anderson $(1981)^{16}$. The reaction mixture containing $50 \mathrm{mM}$ sodium Phoshpate buffer $\mathrm{pH}$ 7.5, $10 \mathrm{mM}$ EDTA, $0.67 \mathrm{mM}$ glutathione oxidized and $0.1 \mathrm{mM}$
NADPH was made up to $3 \mathrm{ml}$ with water. The Change in the optical density was monitored after adding $0.1 \mathrm{ml}$ of sample at $340 \mathrm{~nm}$ for 3 mins at 30 second interval. The enzyme activity is expressed as $n$ moles of GSSG utilized/min/mg protein in plasma sample.

\section{Estimation of Glutathione Peroxidase (GSH-Px)}

Glutathione peroxidase of sample was estimated according to the method of Lawrence and Burk (1976) ${ }^{17}$. The assay mixture consisted $2 \mathrm{ml}$ of $75 \mathrm{mM}$ Phosphate buffer ( $\mathrm{pH} 7.0$ ), $60 \mathrm{mM}$ Glutathione, $0.1 \mathrm{ml}$ of 30 units $/ \mathrm{ml}$ Glutathione reductase, $0.1 \mathrm{ml}$ of $15 \mathrm{mM}$ EDTA, $0.1 \mathrm{ml}$ of $3 \mathrm{mM}$ NADPH and appropriate amount of plasma sample supernatant to final volume of $3.0 \mathrm{ml}$. The reaction was started by the addition of $01 . \mathrm{ml}$ of $7.5 \mathrm{mM} \mathrm{H}_{2} \mathrm{O}_{2}$ The rate of change absorbance during the conversion of NADPH to $\mathrm{NADP}^{+}$was recorded spectrophotometrically at $340 \mathrm{~nm}$ for 3 mins. The activity of glutathione peroxidase was expressed as moles of NADPH oxidized to $\mathrm{NADP}^{+} / \mathrm{min} / \mathrm{mg}$ protein in plasma sample.

\section{Statistical analysis}

The data were expressed as mean \pm standard error mean (S.E.M). The Significance of differences among the group was assessed using one way and multiple way analysis of variance (ANOVA). The test followed by Dunnett's test $p$ values less than 0.05 were considered as significance.

\section{RESULTS AND DISCUSSION}

\section{In-vitro Models for the Evaluation of Antioxidant Activity DPPHMethod}

DPPH methodis the most broadly reported method for screening of anti-oxidant activity of many drugs. DPPH assay method was based on the reduction of methanol solution of coloured free radical DPPH by free radical scavenger. The procedure involved measurement of decrease in absorbance of DPPH at its absorption maxima of $517 \mathrm{~nm}$, which is proportional to concentration of free radical scavenger added to DPPH reagent solution. The test compounds (7a1, 7a2, 7a3, 7a4, 7a5, 7a6, 7a7, 7a8, 7b1, 7b2, 7b3, 7b4, 7b5, 7b6, 7b7 $\& 7 \mathrm{~b} 8)$ at the dose of $100 \mu \mathrm{g} / \mathrm{ml}$ produced a significant reduction $(P<0.001)$ in absorbance of DPPH at its absorption maxima of $517 \mathrm{~nm}$ when 
Table 1. Various substitutions of synthesised compounds

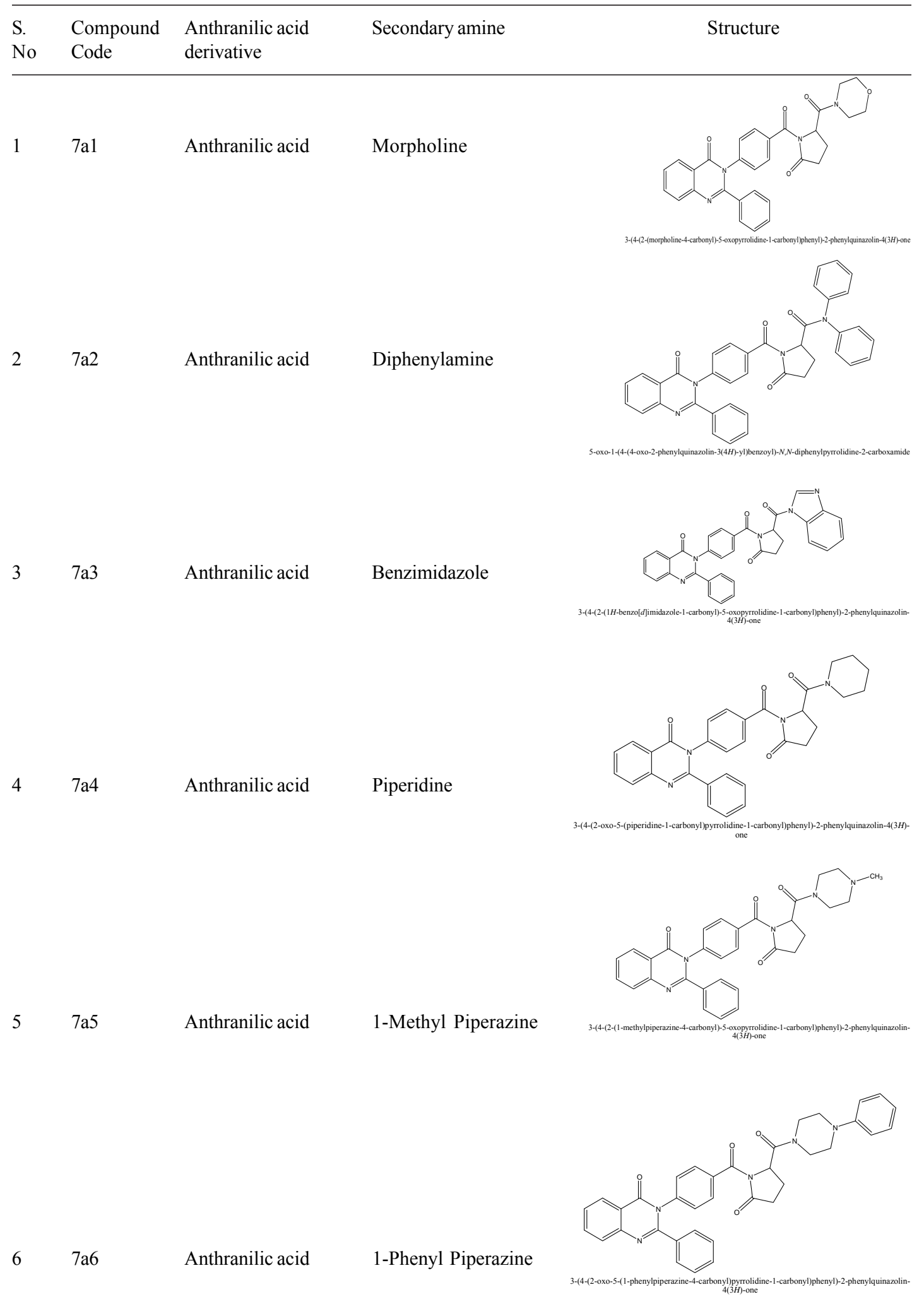


2,6-Dichloro Phenyl Piperazine

\section{Chloro anthranilic acid Morpholine}
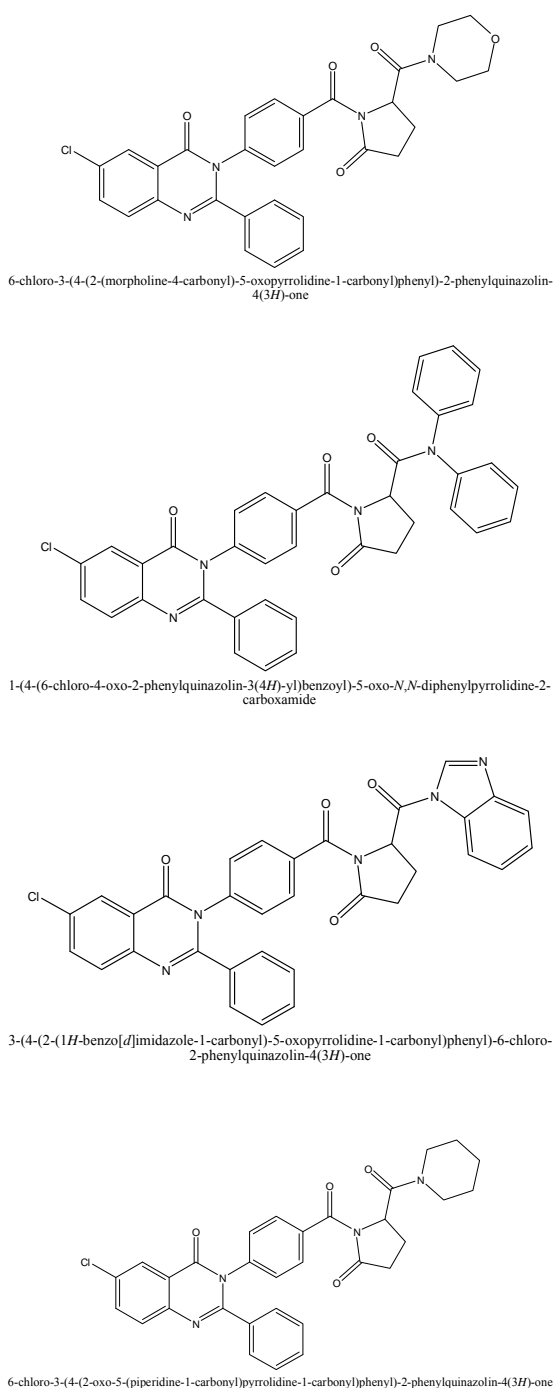
13 $7 b 5$
Chloro anthranilic acid

Chloro anthranilic acid

1-Methyl Piperazine

1-Phenyl Piperazine

Chloro anthranilic acid

Chloro anthranilic acid

1-Ethyl Piperazine

2,6-Dichloro Phenyl

Piperazine
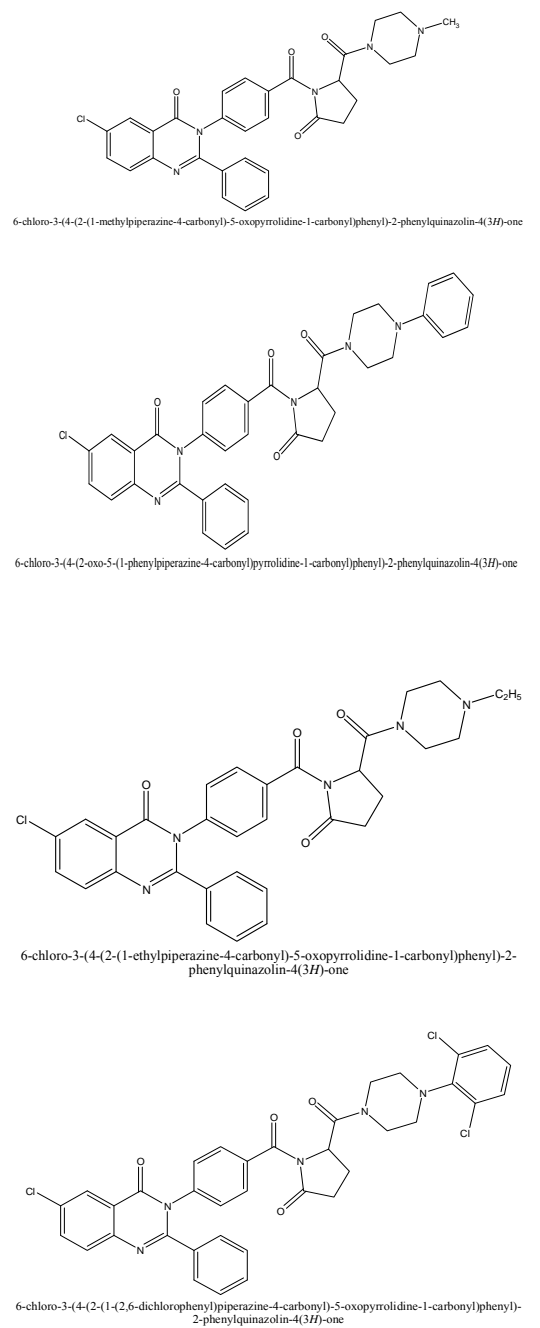

compared to control. These reactions are related \%of scavenging DPPH with test compounds. These anti-oxidant effects were similar to that of Standard (Ascorbic acid100 $\mu \mathrm{g} / \mathrm{ml}$ ) drug.

DPPH radical scavenging activity of each test compounds(7a1, 7a2, 7a3, 7a4, 7a5, 7a6, 7a7, 7a8, 7b1, 7b2, 7b3, 7b4, 7b5, 7b6, 7b7 \& 7b8)added to methanol solution of DPPH and radical scavenging activity was measured as $517 \mathrm{~nm}$ as compared to standard ascorbic acid. Values are the average of triplicate experiments.

\section{Antioxidant activity of Test compounds by reducing} power method

Reducing Power Method is based on the principle of increase in the absorbance of the reaction mixture. Increases in the absorbance indicate increase in the anti-oxidant activity. In this method anti-oxidant compound forms a coloured complex with potassium ferric cyanide, tricloro acetic acid and ferric chloride, which is measured at $700 \mathrm{~nm}$. Increase in the absorbance of the reaction mixture indicate the reducing the power of the samples. The test compounds ( $7 \mathrm{a} 1,7 \mathrm{a} 2,7 \mathrm{a} 3,7 \mathrm{a} 4$, 7a5, 7a6, 7a7, 7a8, 7b1, 7b2, 7b3, 7b4, 7b5, 7b6, 7b7 $\& 7 \mathrm{~b} 8)$ at the dose of $10 \mu \mathrm{g} / \mathrm{ml}$ produced a significant increase $(P<0.001)$ in absorbance of the reaction mixture at its absorption maxima of 700nm when compared to control. These anti-oxidant effects be similar to that of Standard (Ascorbic acid $10 \mu \mathrm{g} / \mathrm{ml})$ drug.

\section{Reducing power of Test compounds of as compared}


to Control and Ascorbic acid. Values are the average of triplicate experiments

Table- 4 shows the effect of Test compounds (7a1, 7a2, 7a3, 7a4, 7a5, 7a6, 7a7, 7a8, $7 \mathrm{~b} 1,7 \mathrm{~b} 2,7 \mathrm{~b} 3,7 \mathrm{~b} 4,7 \mathrm{~b} 5,7 \mathrm{~b} 6,7 \mathrm{~b} 7 \&$ 7b8) on carbon tetrachloride induced oxidative stress. Treatments with the extracts significantly $(\mathrm{P}<0.01)$ prevented the buildup of lipid peroxidation products in the plasma. Intoxication of the rats with carbon tetrachloride also led to significant increases in superoxide dismutase, catalase, glutathione reductase and glutathione peroxidase activities, while simultaneous administration of carbon tetrachloride with the Test compounds (7a1, 7a2,

Table 2. Antioxidant activity of Test compounds by DPPH method

\begin{tabular}{|c|c|c|c|}
\hline S.No. & Sample & Absorbance & $\%$ of scavenging DPPH \\
\hline 1. & Control (Methanol) & $0.602 \pm 0.02$ & - \\
\hline 2. & Standard (Ascorbic acid100 $\mu \mathrm{g} / \mathrm{ml})$ & $0.084 \pm 0.01 * *$ & 86.05 \\
\hline 3. & Compound $7 \mathrm{a} 1(100 \mu \mathrm{g} / \mathrm{ml})$ & $0.156 \pm 0.02 * *$ & 74.08 \\
\hline 4. & Compound 7a2 $(100 \mu \mathrm{g} / \mathrm{ml})$ & $0.134 \pm 0.02 * *$ & 77.74 \\
\hline 5. & Compound 7a3 $(100 \mu \mathrm{g} / \mathrm{ml})$ & $0.146 \pm 0.01 * *$ & 75.75 \\
\hline 6. & Compound 7a4 $(100 \mu \mathrm{g} / \mathrm{ml})$ & $0.174 \pm 0.01 * *$ & 71.09 \\
\hline 7. & Compound 7a5 $(100 \mu \mathrm{g} / \mathrm{ml})$ & $0.118 \pm 0.02 *$ & 80.39 \\
\hline 8. & Compound $7 \mathrm{a} 6(100 \mu \mathrm{g} / \mathrm{ml})$ & $0.144 \pm 0.01 * *$ & 76.08 \\
\hline 9. & Compound 7a7 (100 $\mu \mathrm{g} / \mathrm{ml})$ & $0.126 \pm 0.01 * *$ & 79.07 \\
\hline 10. & Compound $7 \mathrm{a} 8(100 \mu \mathrm{g} / \mathrm{ml})$ & $0.118 \pm 0.02 * *$ & 80.39 \\
\hline 11. & Compound $7 \mathrm{~b} 1(100 \mu \mathrm{g} / \mathrm{ml})$ & $0.128 \pm 0.01 * *$ & 78.74 \\
\hline 12. & Compound $7 \mathrm{~b} 2(100 \mu \mathrm{g} / \mathrm{ml})$ & $0.154 \pm 0.01 * *$ & 74.42 \\
\hline 13. & Compound $7 \mathrm{~b} 3(100 \mu \mathrm{g} / \mathrm{ml})$ & $0.162 \pm 0.02 * *$ & 73.09 \\
\hline 14. & Compound $7 \mathrm{~b} 4(100 \mu \mathrm{g} / \mathrm{ml})$ & $0.122 \pm 0.01 * *$ & 79.73 \\
\hline 15. & Compound $7 \mathrm{~b} 5(100 \mu \mathrm{g} / \mathrm{ml})$ & $0.104 \pm 0.01 * *$ & 82.72 \\
\hline 16. & Compound $7 \mathrm{~b} 6(100 \mu \mathrm{g} / \mathrm{ml})$ & $0.128 \pm 0.01 * *$ & 78.74 \\
\hline 17. & Compound $7 \mathrm{~b} 7(100 \mu \mathrm{g} / \mathrm{ml})$ & $0.166 \pm 0.01 * *$ & 72.43 \\
\hline 18. & Compound $7 \mathrm{~b} 8(100 \mu \mathrm{g} / \mathrm{ml})$ & $0.132 \pm 0.02 * *$ & 78.07 \\
\hline
\end{tabular}

Table 3. Antioxidant activity of Test compounds by reducing power method

\begin{tabular}{lll}
\hline S.No. & Sample & Absorbance \\
\hline 1. & Control (Phosphate buffer) & $0.012 \pm 0.01$ \\
2. & Standard (Ascorbic acid) $(10 \mu \mathrm{g} / \mathrm{ml})$ & $0.956 \pm 0.02 * *$ \\
3. & Compound $7 \mathrm{a} 1(10 \mu \mathrm{g} / \mathrm{ml})$ & $0.724 \pm 0.01 * *$ \\
4. & Compound $7 \mathrm{a} 2(10 \mu \mathrm{g} / \mathrm{ml})$ & $0.766 \pm 0.02 * *$ \\
5. & Compound $7 \mathrm{a} 3(10 \mu \mathrm{g} / \mathrm{ml})$ & $0.822 \pm 0.01 * *$ \\
6. & Compound $7 \mathrm{a} 4(10 \mu \mathrm{g} / \mathrm{ml})$ & $0.854 \pm 0.02 * *$ \\
7. & Compound $7 \mathrm{a} 5(10 \mu \mathrm{g} / \mathrm{ml})$ & $0.896 \pm 0.01 * *$ \\
8. & Compound $7 \mathrm{a} 6(10 \mu \mathrm{g} / \mathrm{ml})$ & $0.814 \pm 0.01 * *$ \\
9. & Compound $7 \mathrm{a} 7(10 \mu \mathrm{g} / \mathrm{ml})$ & $0.852 \pm 0.02 * *$ \\
10. & Compound $7 \mathrm{a} 8(10 \mu \mathrm{g} / \mathrm{ml})$ & $0.902 \pm 0.01 * *$ \\
11. & Compound $7 \mathrm{~b} 1(10 \mu \mathrm{g} / \mathrm{ml})$ & $0.884 \pm 0.02 * *$ \\
12. & Compound $7 \mathrm{~b} 2(10 \mu \mathrm{g} / \mathrm{ml})$ & $0.818 \pm 0.01 * *$ \\
13. & Compound $7 \mathrm{~b} 3(10 \mu \mathrm{g} / \mathrm{ml})$ & $0.848 \pm 0.02 * *$ \\
14. & Compound $7 \mathrm{~b} 4(10 \mu \mathrm{g} / \mathrm{ml})$ & $0.836 \pm 0.02 * *$ \\
15. & Compound $7 \mathrm{~b} 5(10 \mu \mathrm{g} / \mathrm{ml})$ & $0.922 \pm 0.01 * *$ \\
16. & Compound $7 \mathrm{~b} 6(10 \mu \mathrm{g} / \mathrm{ml})$ & $0.866 \pm 0.01 * *$ \\
17. & Compound $7 \mathrm{~b} 7(10 \mu \mathrm{g} / \mathrm{ml})$ & $0.878 \pm 0.02 * *$ \\
18. & Compound $7 \mathrm{~b} 8(10 \mu \mathrm{g} / \mathrm{ml})$ & $0.824 \pm 0.01 * *$ \\
\hline
\end{tabular}




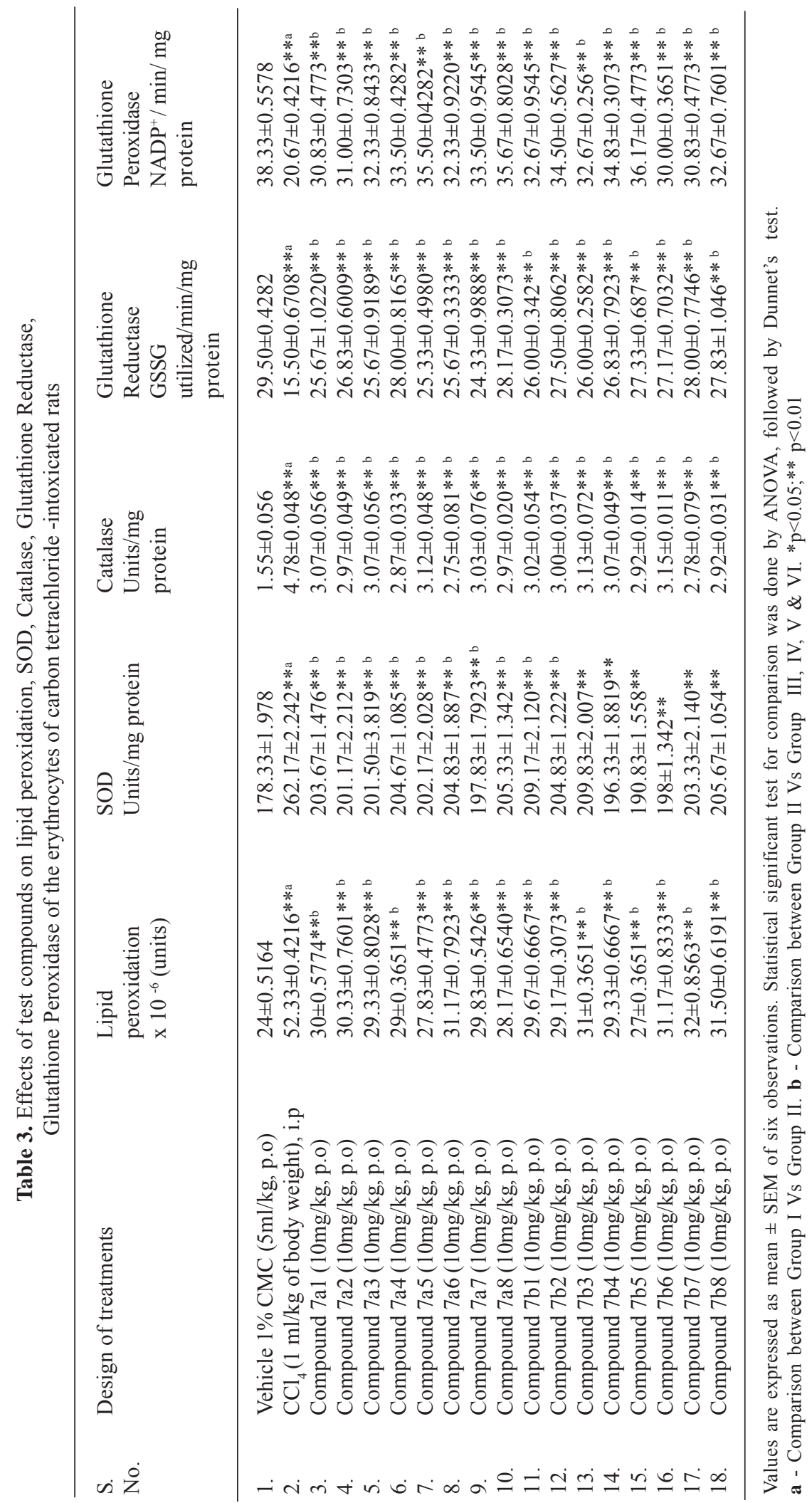


7a3, 7a4, 7a5, 7a6, 7a7, 7a8, 7b1, 7b2, 7b3, 7b4, 7b5, $7 \mathrm{~b} 6,7 \mathrm{~b} 7 \&$ 7b8) significantly $(\mathrm{P}<0.01)$ decreased these activities than control group.

The results of the present study was clearly indicated that the rigidity of the membranes after administration of Test compounds (7a1, 7a2, 7a3, 7a4, 7a5, 7a6, 7a7, 7a8, 7b1, 7b2, 7b3, 7b4, 7b5, $7 \mathrm{~b} 6,7 \mathrm{~b} 7 \& \mathrm{bb} 8)$ at the doses of $10 \mathrm{mg} / \mathrm{kg}$. Many of the researchers proved free radicals are critically involved in various pathological conditions such as cancer, arthritis, inflammation and liver diseases ${ }^{18}$.

In this study, carbon tetrachloride intoxication damage to erythrocytes was confirmed by the elevation of superoxide dismutase, lipid peroxidation and catalase activities, and inversely decreases the glutathione reductase \& glutathione peroxidase in erythrocyte membrane fluidity. The increased superoxide dismutase activity resulted in the accumulation of hydrogen peroxide, which enthused increases in catalase activity. Pretreatment of experimental animals with Test compounds (7a1, 7a2, 7a3, 7a4, 7a5, 7a6, 7a 7, 7a8, 7b1, 7b2, 7b3, 7b4, 7b5, 7b6, 7b7 \& 7b8) exhibited an improved free radical scavenging resulting in decreased activities of superoxide dismutase and catalase and the concentration of lipid peroxidation products towards normal.

In present study results showed that Test compounds (7a1, 7a2, 7a3, 7a4, 7a5, 7a6, 7a7, 7a8, $7 \mathrm{~b} 1,7 \mathrm{~b} 2,7 \mathrm{~b} 3,7 \mathrm{~b} 4,7 \mathrm{~b} 5,7 \mathrm{~b} 6,7 \mathrm{~b} 7$ \& 7b8) significantly decreased lipid peroxidation and increased glutathione peroxidase \& glutathione reductase. Participation of oxygen free radicals and oxidative

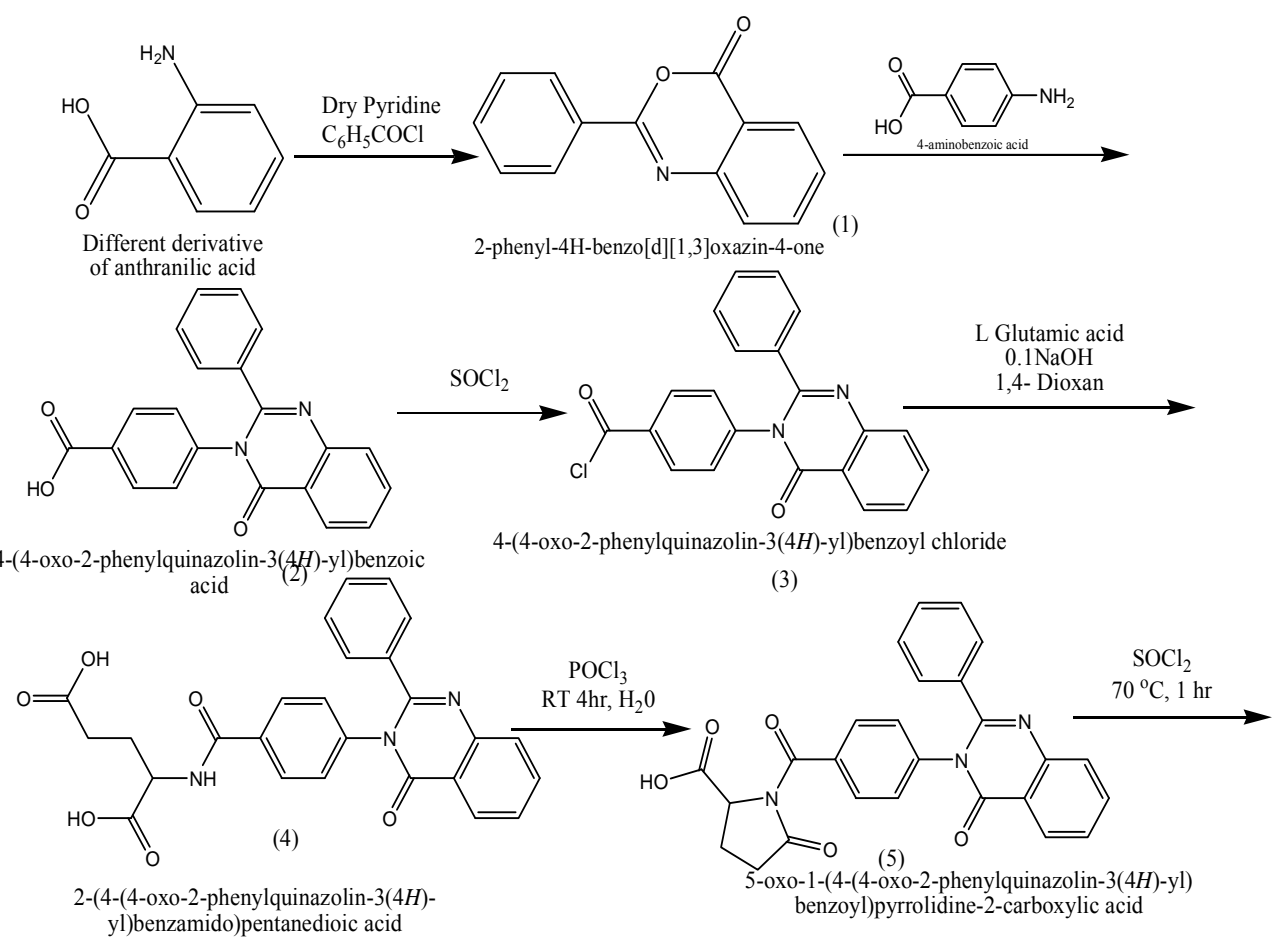

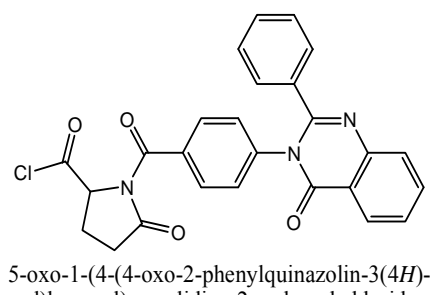

yl)benzoyl)pyrrolidine-2-carbonyl chloride

(6)

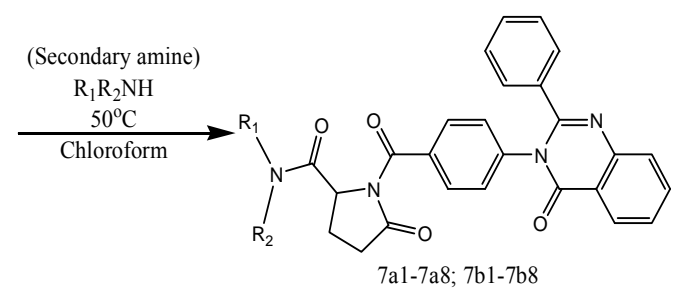

Scheme 1. 
stress in carbon tetrachloride $\left(\mathrm{CCl}_{4}\right)$ induced erythrocyte damage may indirectly be confirmed by antioxidant activity of Test compounds (7a1, 7a2, 7a3, 7a4, 7a5, 7a6, 7a7, 7a8, 7b1, 7b2, 7b3, 7b4, $7 \mathrm{~b} 5,7 \mathrm{~b} 6,7 \mathrm{~b} 7 \& 7 \mathrm{~b} 8)$.

The presence of antioxidants has been reported to protect lipids, blood and body fluids against the attack of reactive oxygen species like superoxide, peroxide and hydroxyl radicals [25-28]. The presence of antioxidants in Test compounds (7a1, 7a2, 7a3, 7a4, 7a5, 7a6, 7a7, 7a8, 7b1, 7b2, 7b3, $7 \mathrm{~b} 4,7 \mathrm{~b} 5,7 \mathrm{~b} 6,7 \mathrm{~b} 7 \&$ 7b8) might be responsible for their observed antioxidant activity. Since reactive oxygen species and free radicals were involved in oxidative stress and pathogenesis of cancer, diabetes mellitus, atherosclerosis, and inflammation, the use of these Test compounds (7a1, 7a2, 7a3, 7a4, 7a5, 7a6, 7a7, 7a8, 7b1, 7b2, 7b3, $7 \mathrm{~b} 4,7 \mathrm{~b} 5,7 \mathrm{~b} 6,7 \mathrm{~b} 7 \&$ 7b8) may be beneficial in preventing initiation or progress of many diseases.

\section{CONCLUSION}

These antioxidants compounds can neutralize free radicals may be of central importance in the prevention of vascular diseases, some forms of cancer and oxidative stress responsible for DNA, protein and membrane damage. The finding of this study suggests that these test compounds can be used as potential source of antioxidant for the treatment of oxidative stress related degenerative diseases.

\section{ACKNOWLEGEMENTS}

The authors wish to thank Sri Ch.Devender Reddy, Secretary and Correspondent, Vaagdevi group of pharmacy colleges, Director, Professor. Y MadhusudhanRao \& Principal Dr.Challa Srinivas Reddy, Vaagdevi College Of Pharmacy, Kishanpura, Warangal, Telangana, India for encouraging and providing facilities to carry out the research work.

\section{REFERENCES}

1. Dan, W., Feng, G. Quinazoline derivatives: synthesis and bioactivities. Chemistry Central Journal., 2013; 7: 95.

2. Abida, Nayyar, P., Arpana, R., Mohd I. An
Updated Review: Newer Quinazoline Derivatives Under Clinical Trial. International Journal of Pharmaceutical \& Biological Archives., 2011; 2(6): 1651-1657.

3. Vijayakumar B., Prasanthi P., Muni Teja K., Mahesh Kumar Reddy, K. Quinazoline Derivatives \& Pharmacological Activities: A Review. International Journal of Medicinal Chemistry \& Analysis., 2013; 3(1): 10-21.

4. E.M. Bulger and R.V. Maier. Antioxidants in critical illness. Arch Surg, 2001; 136(10): 12011207.

5. Faden AI, Demediuk P, Panter SS, Vink R. The role of excitatory amino acids and NMDA receptors in traumatic brain injury. Science, 1989; 244(4906): 798-800.

6. Sen CK, Packer L. Antioxidant and redox regulation of gene transcription. FASEB J., 1996; 10(7): 709- 720 .

7. Gutteridge JMC, Halliwell B. Free radicals and antioxidants in the year 2000 -A historical look to the future. Ann. N. Y. Acad. Sci., 2000; 899: 136-147.

8. B.N. Ames., M.K. Shigenaga., T.M. Hagen. Oxidants, antioxidants, and the degenerative diseases of aging. Proc Natl Acad Sci USA., 1993; 90(17): 7915-7922.

9. Yagi K. Lipid peroxides and human diseases. Chem Phys Lipids., 1987; 45: 337-341.

10. Ames, BN., Cathcart, R., Schwiers, E., Hochstein, P. Uric acid provides an antioxidant defense in humans against oxidantand radical-caused aging and cancer: a hypothesis. Proc Natl Acad Sci USA., 1981; 78: 8658-8662.

11. B.Vijayakumar., C.P. Kumar., G.Sivaprasad., K. Nirosha., Sureka Rokkam \& E.Mohanambal. Evaluation of In Vitro Antioxidant Activity of 1,2,3,4- Tetrahydroquinazoline Derivatives. International Journal of Novel Trends in Pharmaceutical Sciences., 2011; 1(1): 1-5

12. OECD, Acute oral toxicity. Acute oral toxic class method guideline 423 adopted 23.03.1996. In: Eleventh Addendum to the, OECD, guidelines for the testing of chemicals organisation for economical co-operation and development, Paris June, (2002).

13. John M.C. G., Stephanie, W. Copper-dependent hydroxyl radical damage to ascorbic acid. FEBS Letters, 1982; 137(2): 327-400.

14. Marklund, S., Marklund G. Involvement of superoxide anion radical in the autoxidation of pyrogallol: a convenient assay for superoxide dismutase. Eur J Biochem., 1974; 47: 469-474.

15. Beers, R.F. and Sizer, I.W. A spectrophotometric method for measuring the breakdown of hydrogen 
peroxide by catalase. J Biol Chem., 1952; 195: 130-140.

16. Dobler, R.E., Anderson, B.M. Simultaneous inactivation of the catalytic activities of yeast glutathione reductase by $\mathrm{N}$-alkyl melimides. Biochem Biophys Acta., 1981; 70: 659.

17. Lawrence, R.A., Burk R.F. Glutathione peroxidase activity in selenium-deficient rat liver. Biochemical and Biophysical Research Communication., 1976; 71: 952-958.

18. Quambo et al. Hepatoprotective activity of phenylethanoids from Cistanche. Planta Medica., 1998; 64: 120-125. 